\title{
Phosphorylation of membrane proteins in response to temperature in an Antarctic Pseudomonas syringae
}

\author{
M. K. Ray, G. Seshu Kumar and S. Shivaji
}

Author for correspondence: M. K. Ray. Tel: +9140672241 50. Fax: +91 40 851195. Telex: 0425-7046 CCMB IN. e-mail: shivas\%ccmb@uunet.in

Centre for Cellular and Molecular Biology, Uppal Road, Hyderabad 500007 India

\begin{abstract}
Temperature-dependent phosphorylation and dephosphorylation of membrane proteins was studied in vitro in a number of psychrotrophic Antarctic bacteria which grow between 0 and $30^{\circ} \mathrm{C}$. One of them, a Pseudomonas syringae isolate, was studied in detail and was found to have three membrane proteins of molecular mass 30, 65 and $85 \mathrm{kDa}$ which were phosphorylated differently in response to low and high temperatures. The $65 \mathrm{kDa}$ protein was phosphorylated only at lower temperatures (between 0 and $15^{\circ} \mathrm{C}$ ). The $30 \mathrm{kDa}$ protein was phosphorylated more at higher temperatures and was possibly a histidine kinase. This protein was present in all the psychrotrophic Pseudomonas species studied and in Sphingobacterium antarcticus. A possible role for these proteins in sensing environmental temperature is proposed.
\end{abstract}

Keywords: Antarctic psychrotrophs, Pseudomonas syringae, phosphorylation of proteins, temperature sensing

\section{INTRODUCTION}

Sensing environmental signals is of primary importance for adaptation in living systems. Bacteria, in general, use a 'two-component' regulatory system to achieve this (Bourret et al., 1991; Stock et al., 1989). In this system a 'sensor' molecule, usually a histidine kinase in the cell membrane, is activated by phosphorylation and the signal is transduced to the cytoplasmic 'regulator' protein by transphosphorylation of an aspartic acid residue. The regulator proteins generally act as transcription activators and therefore alter the pattern of gene expression. However, the sensing of environmental temperature, or thermosensory transduction, in bacteria remains little understood, although models have been proposed for mesophilic bacteria. An earlier study indicated the possible involvement of a chemosensory transducing pathway in thermosensory transduction in Eschericbia coli (Maeda \& Imae, 1979). More recently DnaK, a member of the heat-shock protein family of hsp 70, was implicated as a cellular thermometer in E. coli (Craig \& Gross, 1991; McCarty \& Walker, 1991). The heat-shock sigma factor $\left(\sigma^{32}\right)$ which regulates the expression of the heat-shock genes (Straus et al., 1987, 1990) also controls the expression of DnaK. It is therefore likely that there exists a primary thermosensory transducing pathway which would interact with the specific sigma factor(s) and bring about expression of specific sets of genes so as to adapt to higher or lower temperatures. In pathogenic yersiniae (Yersinia pestis, Y. enterolytica and $Y$. pseudotuberculosis) the genes such as $\operatorname{lcr} F$ or the homologous $\operatorname{vir} F$ have been implicated in temperature sensing, for virulence and pathogenesis (Hoe et al., 1992; Hoe \& Goguen, 1993). However, nothing is known about how psychrotrophic bacteria sense environmental temperatures.

In our studies with Antarctic micro-organisms (Jagannadham et al., 1991; Ray \& Shivaji, 1992; Ray et al., 1989, 1991, 1992, 1994a, b; Shivaji et al., 1988, 1989a, b, 1991, 1992; Chauhan \& Shivaji, 1994) we observed that psychrotrophic bacteria could grow at temperatures between 0 and $30^{\circ} \mathrm{C}$ and that their transcription and translation machinery was well adapted to function at $0{ }^{\circ} \mathrm{C}$. Therefore, the Antarctic psychrotrophic bacteria could provide us with a unique model to study coldadaptive features as well as adaptive responses to environmental temperatures. In one of the psychrotrophs, Pseudomonas syringae, the cold-inducible expression of certain genes and the existence of more than one sigma factor, including a cold-specific one, were also observed (unpublished observation). This indicated that differential expression of genes in response to temperature fluctuation (which is common in soil systems of continental Antarctica) could be the consequence of a primary temperaturesensing mechanism. Since the phosphorylation-dephosphorylation mechanism has been implicated in the primary 
sensory transduction pathway of various environmental stimuli (Bourret et al., 1991; Stock et al., 1989), the temperature-dependent phosphorylation of membrane proteins was studied. It was observed that low temperature induced the phosphorylation of a $65 \mathrm{kDa}$ membrane protein. Two other membrane proteins, of 30 and $85 \mathrm{kDa}$, were observed to be phosphorylated in response to higher temperature. Pulse-labelling of $P$. syringae cells with ${ }^{32} \mathrm{P}_{1}$ in vivo suggested that phosphorylation of these proteins could change in response to low and high temperature. Therefore, a possible role of these proteins in sensing temperature has been suggested.

\section{METHODS}

Bacterial strains and growth conditions. All the bacterial strains from soil samples of Antarctica were identified and maintained as previously reported (Shivaji et al., 1989a). All the strains were psychrotrophic with an optimal growth temperature of about $22^{\circ} \mathrm{C}$. They were routinely grown in ABM (Antarctic bacterial medium, which contains bactopeptone, $0.5 \%, \mathrm{w} / \mathrm{v}$, and yeast extract, $0.2 \%, \mathrm{w} / \mathrm{v}$ ) at room temperature $\left(\sim 22{ }^{\circ} \mathrm{C}\right)$ (Shivaji et al., 1989a). The strains used in this study were $P$. syringae Lz4W, P. fuorescens $1 \mathrm{~W}, P$. fuorescens $9 \mathrm{AW}, P$. fuorescens 39W (Shivaji et al., 1989a), Artbrobacter globiformis 4B2W (Shivaji et al., 1989b), Micrococcus sp. 30Y, Planococcus sp Lz30R (Shivaji et al., 1988) and Spbingobacterium antarcticus 6BY (Shivaji et al., 1992).

Isolation of bacterial membranes and cytosol. The bacterial membranes were prepared by a method similar to that of Schnaitman (1971). Briefly, the cells were treated with lysozyme $\left(60 \mu \mathrm{g} \mathrm{ml}^{-1}\right)$ in the membrane buffer $(10 \mathrm{mM}$ Tris, $\mathrm{pH} 8.0$, $0.75 \mathrm{M}$ sucrose, $2 \mathrm{mM}$ EDTA and $1 \mu \mathrm{M}$ PMSF) and sonicated for $2 \mathrm{~min}$ in a Branson sonifier in which the duty control switch was set at $40 \%$ and the output knob at 3 (power output of $70 \mathrm{~W})$. The unbroken cells were removed by centrifugation at 8000 r.p.m. for $10 \mathrm{~min}$ in a Sorvall centrifuge. The total membrane fraction was pelleted by ultracentrifugation at 30000 r.p.m. for $2 \mathrm{~h}$ at $4^{\circ} \mathrm{C}$ in a TL-100 table-top ultracentrifuge (Beckman). The supernatant was used as the cytosol fraction in this study. The inner membrane proteins were solubilized with $2 \%(\mathrm{v} / \mathrm{v})$ Triton $\mathrm{X}-100$ in the membrane buffer for $30 \mathrm{~min}$ at room temperature $\left(\sim 22^{\circ} \mathrm{C}\right)$. After centrifugation at 30000 r.p.m. for $2 \mathrm{~h}$, the supernatant was used as the inner membrane protein fraction. The outer membrane proteins were not solubilized under the above conditions (Schnaitman, 1971). For experimental purposes, the pellet of outer membrane was suspended in the membrane buffer and the suspension was used for phosphorylation assay.

Assay of phosphorylation activity. The phosphorylation assay in vitro was carried out with Triton X-100 solubilized membrane proteins. Briefly $30-40 \mu \mathrm{g}$ of the membrane proteins were incubated in $10 \mathrm{mM}$ Tris $/ \mathrm{HCl}(\mathrm{pH} \mathrm{7.6})$ and $5 \mathrm{mM} \mathrm{MgCl}$ for $10 \mathrm{~min}$ at $0,5,10,15,20,22,25$ and $30^{\circ} \mathrm{C}$ and the phosphorylation reaction was started with the addition of $20 \mathrm{nM}\left[\gamma^{32} \mathrm{P}\right]$ ATP $\left(3000 \mathrm{Ci} \mathrm{mmol}^{-1} ; 111 \mathrm{TBg} \mathrm{mmol}^{-1}\right)$. For assay of phosphorylation in presence of $\left[\gamma^{32} \mathrm{P}\right] \mathrm{GTP}$ or $[\alpha-$ ${ }^{32}$ P]ATP the equivalent amount, i.e. $20 \mathrm{nM}\left(3000 \mathrm{Ci} \mathrm{mmol}^{-1}\right)$, of the respective nucleotide was used instead of $\left[\gamma_{-}{ }^{32} \mathrm{P}\right]$ ATP. After $10 \mathrm{~min}$ an equal volume of $2 \times$ sample buffer was added, boiled for $2 \mathrm{~min}$, cooled and analysed on an SDS-polyacrylamide gel (Laemmli, 1970). The phosphorylated proteins were visualized by autoradiography. For quantification, the radioactive bands on the dried gel (identified with the help of the corresponding autoradiogram) were cut out and the associated radioactivity was measured directly (dry count) in a scintillation counter. It is to be noted that the average delay between the actual day of the experiment and the counting of radioactivity of the gel fragments was about 5-6d. Therefore the radioactivity data shown in Figs 2 and 3 are less than the actual incorporation. Also to be noted is the fact that the efficiency of a dry count is less than that in the presence of a liquid scintillant. Nevertheless the data presented in the figures are proportionate to the intensity of the bands seen in the autoradiograms.

Phosphorylation study in vivo. For in vivo phosphorylation, $P$. syringae cells $\left(\mathrm{OD}_{600} 0.6\right)$ were pulsed in the presence of ${ }^{32} \mathrm{P}$ labelled orthophosphate $(35 \mu \mathrm{Ci}$ per $\mathrm{ml}$ culture) for $30 \mathrm{~min}$ at $4{ }^{\circ} \mathrm{C}$, or for $15 \mathrm{~min}$ at $22^{\circ} \mathrm{C}$. The cells were pelleted, washed and transferred into fresh ABM medium which was preincubated at the desired temperature. At the respective time points the cells were pelleted by centrifugation either at $22^{\circ} \mathrm{C}$ or at $4{ }^{\circ} \mathrm{C}$ and lysed in the SDS sample buffer of Laemmli (1970) by boiling for 2-5 min and analysed on an SDS-polyacrylamide gel. During labelling with $\left[\gamma_{-}^{32} \mathrm{P}\right] \mathrm{ATP}$, the cells were incubated in ABM medium in the presence of $100 \mu \mathrm{Ci}$ labelled nucleotide for $30 \mathrm{~min}$ to $1 \mathrm{~h}$ and processed as above. It is to be noted that the temperatures chosen for phosphorylation experiments were $4{ }^{\circ} \mathrm{C}$ (for lower temperature) and $22^{\circ} \mathrm{C}$ (for higher temperature), unlike most of the in vitro experiments, where 0 and $30^{\circ} \mathrm{C}$ were used. This was because $30^{\circ} \mathrm{C}$ was the maximum growth temperature for the psychrotrophs and could have caused unwanted stress to the cells. The selection of $4{ }^{\circ} \mathrm{C}$ as the lower temperature for in vivo phosphorylation was simply due to the fact that growing cells at $4{ }^{\circ} \mathrm{C}$ was easier.

Acid and alkali stability of proteins and analysis of phosphoamino acids. Acid and alkali stability of the phosphorylated proteins was studied at $50^{\circ} \mathrm{C}$ for $10 \mathrm{~min}$ or at $37^{\circ} \mathrm{C}$ for $20 \mathrm{~min}$ in the presence of $0.1 \mathrm{M} \mathrm{HCl}$ and $0.1 \mathrm{M} \mathrm{NaOH}$ respectively, according to the method of Mukai et al. (1990). For analysis of the phosphoamino acid, the in vitro ${ }^{32} \mathrm{P}$-labelled phosphorylated proteins were transferred on to Immobilon-P membrane (Millipore) by the method of Kyhse-Anderson (1984). After visualizing the protein bands following autoradiography, the band corresponding to the $30 \mathrm{kDa}$ protein was cut out and the protein in the membrane strip was hydrolysed in $3 \mathrm{M} \mathrm{KOH}$, neutralized and analysed by paper chromatography as described by Smith et al. (1978).

\section{RESULTS AND DISCUSSION}

\section{Phosphorylation of membrane-associated proteins in vitro}

Membrane-associated proteins are expected to be likely candidates for sensing environmental conditions. Therefore to localize the protein which was phosphorylated following cold treatment, the total cell membranes of $P$. syringae were phosphorylated in the presence of $[\gamma-$ ${ }^{32}$ P]ATP. SDS-PAGE analysis and subsequent autoradiography revealed that a $65 \mathrm{kDa}$ protein was phosphorylated specifically at $0{ }^{\circ} \mathrm{C}$. The corresponding protein band was not visible in the Coomassie-Blue-stained gel, indicating that the protein was present in a minute quantity. Temperature dependence of the cold-induced labelling of the $65 \mathrm{kDa}$ proteins suggested that the phosphorylation takes place between 0 and $15^{\circ} \mathrm{C}$ (data not shown). Above $20^{\circ} \mathrm{C}$ the $65 \mathrm{kDa}$ protein was not 
(a)

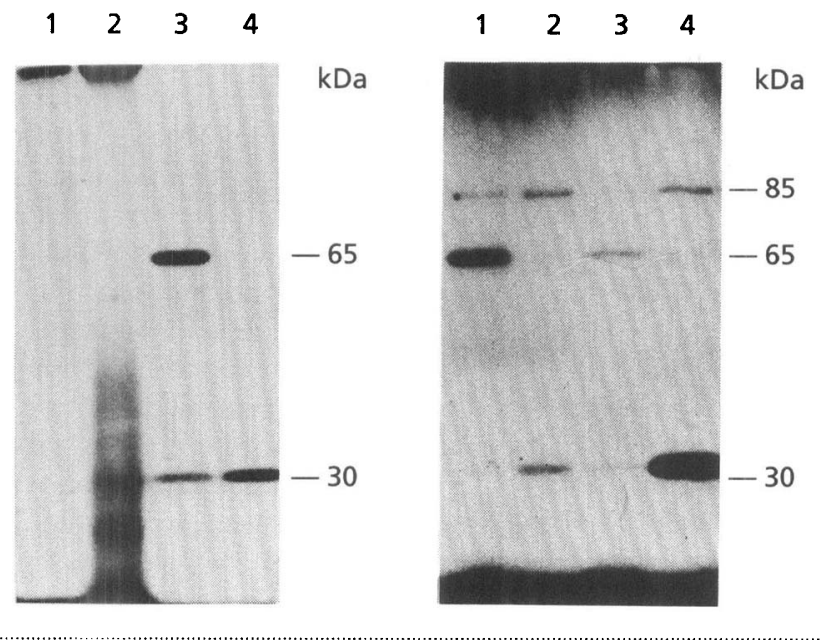

Fig. 1. Phosphorylation of outer and inner membrane proteins of $P$. syringae. (a) Phosphorylated proteins of outer membrane at $0^{\circ} \mathrm{C}$ (lane 1) and at $30^{\circ} \mathrm{C}$ (lane 2) and of inner membrane at $0^{\circ} \mathrm{C}$ (lane 3) and at $30^{\circ} \mathrm{C}$ (lane 4). The autoradiogram was developed after $6 \mathrm{~h}$. The $85 \mathrm{kDa}$ band is not clearly visible in this figure. (b) Triton X-100 solubilized membrane fraction was phosphorylated in the presence of either [ $\gamma-{ }^{32}$ P]ATP or $[\gamma$ ${ }^{32} \mathrm{PJGTP}$ at $0^{\circ} \mathrm{C}$ or $30^{\circ} \mathrm{C}$ for $10 \mathrm{~min}$ and analysed by SDS-PAGE and autoradiography. Lane $1,\left[\gamma-{ }^{32} \mathrm{P}\right] A T P, 0{ }^{\circ} \mathrm{C}$; lane $2,[\gamma-$ $\left.{ }^{32} \mathrm{P}\right] \mathrm{ATP}, 30^{\circ} \mathrm{C}$; lane $3,\left[\gamma^{32} \mathrm{P}\right] \mathrm{GTP}, 0^{\circ} \mathrm{C}$; lane $4,\left[\gamma-{ }^{32} \mathrm{P}\right] \mathrm{GTP}, 30^{\circ} \mathrm{C}$ All the phosphorylated protein bands including the $85 \mathrm{kDa}$ band are distinctly visible.

phosphorylated but two other proteins ( 30 and $85 \mathrm{kDa}$ ) were observed to be phosphorylated more at higher temperatures (e.g. at $30^{\circ} \mathrm{C}$ ) in the inner membrane (Fig. $1 \mathrm{a}, \mathrm{b})$. Triton X-100 solubilization of the total membrane (Schnaitman, 1971) indicated that all three proteins were associated with the inner membrane (Fig. 1a). The few phosphorylated bands seen to be associated with the outer membrane (Fig. 1a, lane 2) were probably due to phosphorylation of lipopolysaccharides rather than proteins (unpublished observation; Ray et al., 1994b).

While both $\left[\gamma_{-}^{32} \mathrm{P}\right]$ ATP and $\left[\gamma_{-}{ }^{32} \mathrm{P}\right] \mathrm{GTP}$ could act as phosphate donors for the phosphorylation of the three proteins, $\left[\gamma_{-}{ }^{32} \mathrm{P}\right]$ GTP acted as a better phosphate donor for the $30 \mathrm{kDa}$ protein (Fig. 1b). In contrast, $\left[\gamma^{-32} \mathrm{P}\right] \mathrm{ATP}$ acted as a better donor for phosphorylation of the $65 \mathrm{kDa}$ protein. Solubilization of the phosphorylated reaction mixture in Laemmli sample buffer at 25 and $100{ }^{\circ} \mathrm{C}$ did not alter the mobility of the phosphoproteins in the SDSpolyacrylamide gels (data not shown). Therefore, it is likely that the three phosphorylated proteins represent three different species, rather than the dimer or oligomer of the $30 \mathrm{kDa}$ protein. It is also to be noted that $[\alpha-$ $\left.{ }^{32} \mathrm{P}\right]$ ATP could not phosphorylate these proteins, ruling out the possibility that the observed phosphorylation was due to adenylylation (data not shown).

Time kinetics of in vitro phosphorylation of the three proteins (Fig. 2) indicated that at $30^{\circ} \mathrm{C}$ the $30 \mathrm{kDa}$ protein was phosphorylated to a maximum extent within $15 \mathrm{~s}$ and reached a plateau value by 2 min but subsequently reduced to a basal level after 30 min (data not shown). However,

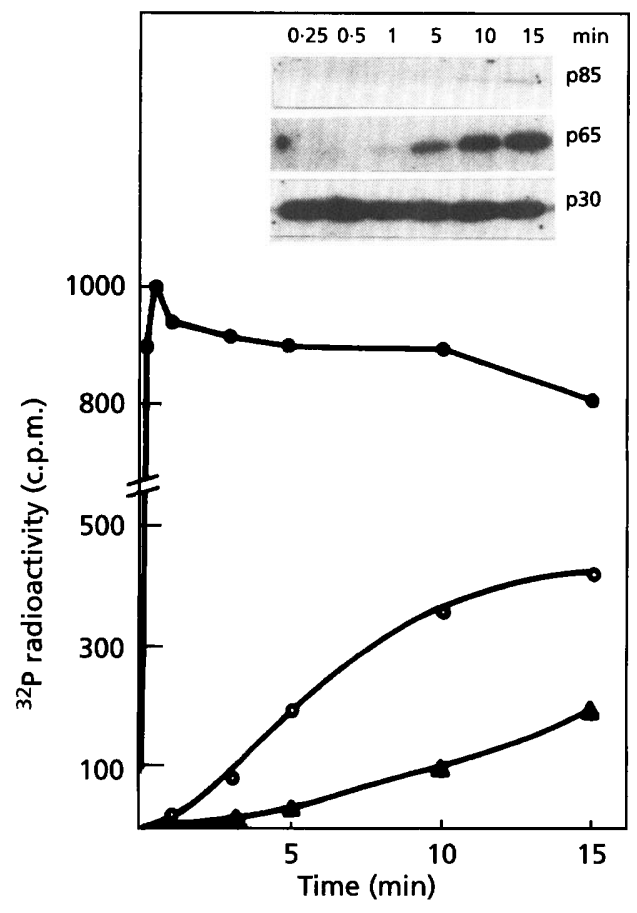

Fig. 2. Kinetics of phosphorylation of the membrane proteins of $P$. syringae. Triton $\mathrm{X}-100$ solubilized membrane proteins were phosphorylated in the presence of $\left[\gamma-{ }^{32} \mathrm{P}\right] \mathrm{ATP}$ at 0 and at $30{ }^{\circ} \mathrm{C}$ for various periods (15 $\mathrm{s}$ to $15 \mathrm{~min}$ ) and resolved by SDSPAGE. After visualization of the phosphorylated protein bands by autoradiography, the bands were cut from the gel and counted directly (dry count) in a liquid scintillation counter. The counts associated with the $30 \mathrm{kDa}(O)$ and $85 \mathrm{kDa}$ (A) proteins were plotted from the kinetics of the $30^{\circ} \mathrm{C}$ reaction, and the $65 \mathrm{kDa}(\mathrm{O})$ protein counts were from the $0^{\circ} \mathrm{C}$ reaction mixture. The inset shows the results of one such analysis. The bands corresponding to the $30 \mathrm{kDa}$ protein (p30) and the $85 \mathrm{kDa}$ protein (p85) were exposed for $16 \mathrm{~h}$ and the band corresponding to the $65 \mathrm{kDa}$ protein (p65) was exposed for $30 \mathrm{~h}$. The results are from the same gel.

in contrast, the $85 \mathrm{kDa}$ protein at $30^{\circ} \mathrm{C}$ was phosphorylated only after $5 \mathrm{~min}$ and the phosphorylation steadily increased, reaching a plateau after 15-20 min. The low temperature $\left(0^{\circ} \mathrm{C}\right)$ induced phosphorylation of the $65 \mathrm{kDa}$ protein was observed after $1 \mathrm{~min}$, reaching a maximum after 15-30 min. The fate of these three proteins following phosphorylation at 0 or $30^{\circ} \mathrm{C}$ and subsequent temperature shift to 30 or $0^{\circ} \mathrm{C}$ was also monitored. When the phosphorylation reaction was carried out at $0^{\circ} \mathrm{C}$ in the presence of $\left[\gamma_{-}{ }^{32} \mathrm{P}\right]$ ATP and then shifted to $30^{\circ} \mathrm{C}$, the intensity of the 65 and $85 \mathrm{kDa}$ phosphorylated proteins showed a time-dependent inverse kinetic relationship (Fig. 3a, b). Further, the $30 \mathrm{kDa}$ protein under similar temperature-shift conditions exhibited increased phosphorylation immediately after the temperature shift but remained more or less unchanged afterwards. Interestingly, in the reverse temperature-shift experiment (30 to $0^{\circ} \mathrm{C}$ ), the status of phosphorylation of the 30 and $85 \mathrm{kDa}$ proteins did not alter significantly (Fig. 3a, c) but the $65 \mathrm{kDa}$ protein, which was not phosphorylated at $30{ }^{\circ} \mathrm{C}$, appeared to become phosphorylated slowly, reach- 
(a)

$$
\begin{array}{llllllllllll} 
& 0^{\circ} \mathrm{C} \longrightarrow & 30^{\circ} \mathrm{C} \longrightarrow & & & & 30^{\circ} \mathrm{C} \longrightarrow & 0^{\circ} \mathrm{C} & \\
1 & 2 & 3 & 4 & 5 & 6 & 7 & 8 & 9 & 10 & 11 & 12
\end{array}
$$
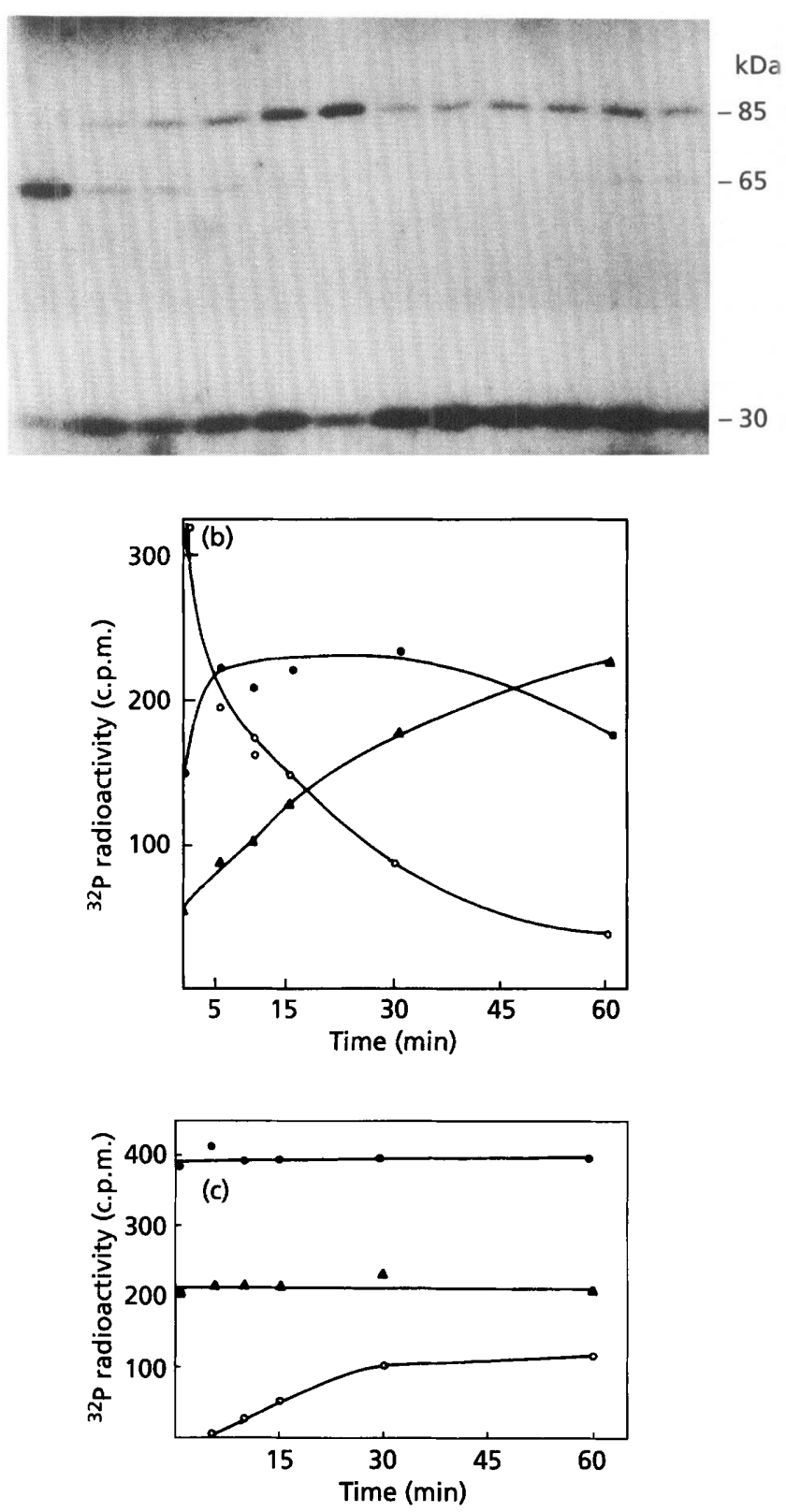

Fig. 3. Kinetics of phosphorylation of the membrane proteins of $P$. syringae. (a) Triton $X-100$ solubilized membrane proteins were phosphorylated in the presence of [ $\left.\gamma-{ }^{32} \mathrm{P}\right]$ ATP for $10 \mathrm{~min}$ at 0 and $30^{\circ} \mathrm{C}$ and then transferred to 30 and $0^{\circ} \mathrm{C}$, respectively. After transfer, equal aliquots were collected from the tube at various time points ( 0 to $60 \mathrm{~min}$ ) and analysed by SDS-PAGE and autoradiography. Lanes 1 to 6 are the products of transfer from 0 to $30^{\circ} \mathrm{C}$ at $0,5,10,15,30$ and $60 \mathrm{~min}$, respectively. Lanes 7 to 12 are the products of transfer from 30 to $0^{\circ} \mathrm{C}$ at the same time intervals, respectively. (b, c) After autoradiographic visualization of the protein bands, the gel pieces corresponding to each labelled band were cut out and the radioactivity was measured directly (dry count) in a liquid scintillation counter. (b) Results of the 0 to $30^{\circ} \mathrm{C}$ transfer reaction. (c) Results of the 30 to $0^{\circ} \mathrm{C}$ transfer reaction. $0,30 \mathrm{kDa}$ protein; $0,65 \mathrm{kDa}$ protein; $\Delta, 85 \mathrm{kDa}$ protein. The points are the means of the data from two gels. ing a maximum after $30 \mathrm{~min}$. It is to be noted here that in these experiments the unincorporated $\left[\gamma^{32}\right.$ P $]$ ATP molecules were not separated from the reaction mixture. Following separation of the proteins from unincorporated $\left[\gamma^{32} \mathrm{P}\right]$ A TP by passing through a column (NucTrap probe purification column, Stratagene), it was found that the other proteins whose phosphorylation was temperature (high or low) dependent did not become labelled on temperature-shift. This indicated that the change of phosphorylation pattern was not due to a phosphotransfer reaction but due to separate kinase reactions. Although the actual relationship of phosphorylation-dephosphorylation between these proteins could not be established in these experiments, it could be argued that the phosphorylation status of these three proteins was modulated by temperature, and hence may enable the bacterium to sense the environmental temperatures. However, in some experiments during 30 to $0^{\circ} \mathrm{C}$ shift (Fig. 3a) the $85 \mathrm{kDa}$ protein showed a slight increase in phosphorylation. The reason for this is not clear.

\section{Phosphorylation of proteins in cells in vivo}

Experiments with intact cells incubated in the presence of carrier-free ${ }^{32} \mathrm{P}$-labelled orthophosphate or with $[\gamma$ ${ }^{32}$ P]ATP (Fig. 4a) also indicated that membrane proteins were phosphorylated. At $4{ }^{\circ} \mathrm{C}$, phosphorylation of the $65 \mathrm{kD}$ a protein in $P$. syringae was observed. However, this temperature-dependent phosphorylation does not necessarily establish that the cells use this as a mechanism to sense temperature. Therefore, an attempt was made to pulse-label the cells with ${ }^{32} \mathrm{P}_{\mathbf{i}}$ in $\mathrm{ABM}$ medium and the phosphorylation of proteins was studied following a shift of temperature (Fig. 4b). The results indicate that when the cells were pulse-labelled for $15 \mathrm{~min}$ at room temperature $\left(\sim 22{ }^{\circ} \mathrm{C}\right)$ and then transferred to $4{ }^{\circ} \mathrm{C}$ they did not show much alteration in the radioactive intensity of the $30 \mathrm{kDa}$ protein up to $1 \mathrm{~h}$. However, the $30 \mathrm{kDa}$ band increased in intensity within 5 min after the culture temperature was raised back to $22{ }^{\circ} \mathrm{C}$. The protein band again lost its intensity after $1 \mathrm{~h}$ when the temperature was reduced to $4^{\circ} \mathrm{C}$. This repeated dynamic change of radioactivity of the $30 \mathrm{kDa}$ band reflects a strong correlation of phosphorylation-dephosphorylation state with a shift of temperature, and therefore implies a possible thermosensing role. The cold-induced phosphorylated protein of $65 \mathrm{kDa}$, however, was not as prominent as the $30 \mathrm{kDa}$ protein in this in vivo pulse-chase experiment. Moreover, the $65 \mathrm{kDa}$ region of the gel is masked by intense non-specific background radioactivity due to labelled lipopolysaccharides and other unknown materials (unpublished observation). The higher-temperature-induced $85 \mathrm{kDa}$ protein was also noticeable in the experiment (Fig. 4b). It is important to note that in these experiments distinction could not be made between membrane and cytosolic proteins and the assignment of the protein is based on their molecular masses and acidand alkali-stability (Fig. 4c). However, after a longer exposure (about $3 \mathrm{~d}$ or more) a greater number of proteins were visible along with a high background which might contain the labelled cytosolic proteins. 
(a)

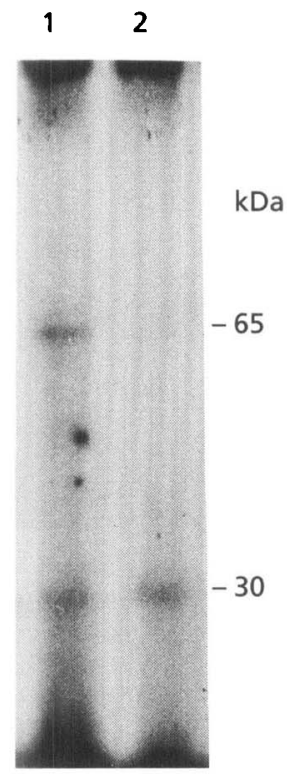

(b)

$\begin{array}{llllllllll}1 & 2 & 3 & 4 & 5 & 6 & 7 & 8 & 9 & 10\end{array}$

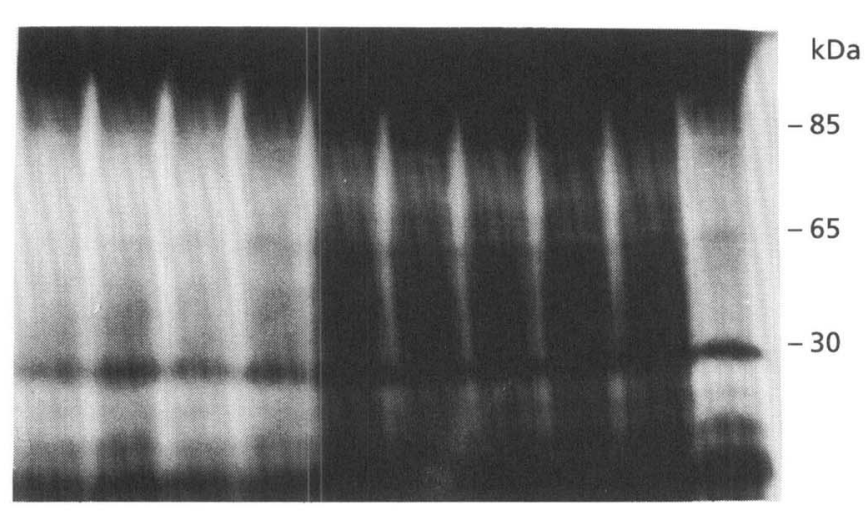

(c) $\begin{array}{llll}1 & 2 & 3 & 4\end{array}$

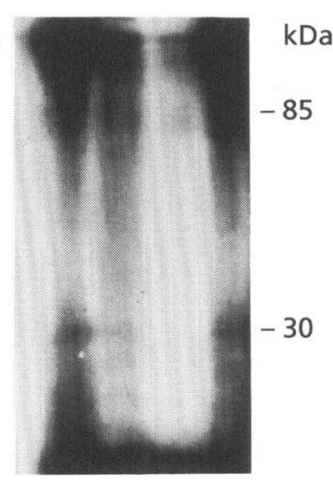

Fig. 4. In vivo phosphorylation of $P$. syringae cells. (a) Cells were labelled with $\left[\gamma-{ }^{32} \mathrm{P}\right] \mathrm{ATP}$ at $4{ }^{\circ} \mathrm{C}$ (lane 1 ) and at $22^{\circ} \mathrm{C}$ (lane 2). The samples were analysed by $10 \%$ SDS-PAGE and visualized by autoradiography. (b) Pulse-labelling experiments of $P$. syringae cells with ${ }^{32} \mathrm{P}_{\mathrm{i}}$. The growing cells were pulsed with ${ }^{32} \mathrm{P}_{\mathrm{i}}$ for $15 \mathrm{~min}$ at $22{ }^{\circ} \mathrm{C}$ (lane 1 ), washed and then transferred to $4{ }^{\circ} \mathrm{C}$ for $15 \mathrm{~min}$ (lane 2), $30 \mathrm{~min}$ (lane 3) and $1 \mathrm{~h}$ (lane 4). The cells were again transferred back to $22^{\circ} \mathrm{C}$ for $5 \mathrm{~min}$ (lane 5), $15 \mathrm{~min}$ (lane 6), $30 \mathrm{~min}$ (lane 7) and $1 \mathrm{~h}$ (lane 8) and retransferred to $4{ }^{\circ} \mathrm{C}$ for $15 \mathrm{~min}$ (lane 9 ) and $1 \mathrm{~h}$ (lane 10). The samples were lysed directly in SDS sample buffer by boiling for $2 \mathrm{~min}$ and analysed on a $10 \%$ SDS-PAGE and by autoradiography. (c) Acid- and alkali-stability of in vivo ${ }^{32}$ P-labelled proteins. Lane 1, cells were directly analysed after ${ }^{32} \mathrm{P}$ labelling at $22{ }^{\circ} \mathrm{C}$; SDS-lysed cells were incubated in $0.1 \mathrm{M} \mathrm{NaOH}$ (lane 2), $0.1 \mathrm{M} \mathrm{HCl}$ (lane 3) or $0.1 \mathrm{M} \mathrm{Tris/HCl,} \mathrm{pH} \mathrm{7.5} \mathrm{(lane}$ 4) before analysis on $10 \%$ SDS-PAGE.

The phosphorylation of cytoplasmic membrane proteins by $\left[\gamma-{ }^{32} \mathrm{P}\right] \mathrm{ATP}$ in intact cells is interesting since $[\gamma-$ ${ }^{32}$ P]ATP cannot normally penetrate cells and hence it is likely that the temperature sensing proteins (65 and $30 \mathrm{kDa}$ ) are probably accessible from the periplasmic side of the cells. Another possible explanation could be that the $\left[\gamma_{-}{ }^{32} \mathrm{P}\right]$ ATP was broken down into its constituents, and the ${ }^{32} \mathrm{P}_{\mathrm{i}}$ thus liberated re-entered the cytoplasmic nucleotide pool and phosphorylated the proteins.

\section{Nature of phosphorylation and phosphorylated proteins}

The acid- and alkali-stability of phosphate groups of a protein generally provide a preliminary indication of the type of bond by which the phosphate groups are attached to the amino acids and thereby also suggest the nature of amino acids which are phosphorylated (Smith, 1984; Mukai et al., 1990; Roy Chowdhury et al., 1992). While $N$ linked phosphates are acid-labile but alkali-stable, the acyl phosphates are both acid- and alkali-labile. Among $O$ linked phosphates, tyrosine phosphates are both acid- and alkali-stable whereas serine and threonine phosphates are acid-stable but alkali-labile (Martensen, 1984; Fujitaki \& Smith, 1984). Therefore acid- and alkali-stability of the phosphorylated membrane proteins of $P$. syringae was studied. Table 1 and Fig. 5(a) summarize the acid and alkali lability of the various phosphorylated proteins from the membrane. The data indicate that the $30 \mathrm{kDa}$ mem-
Table 1. Acid- and alkali-stability of the temperaturemodulated phosphorylated proteins of $P$. syringae

Stability was determined in $0 \cdot 1 \mathrm{M} \mathrm{HCl}$ or $0 \cdot 1 \mathrm{M} \mathrm{NaOH}$ at $50^{\circ} \mathrm{C}$ as described in Methods. -, Not stable; + , stable.

\begin{tabular}{|llll|}
\hline Temperature & Protein & Stability \\
\cline { 2 - 4 } & & Acid Alkali \\
\hline Low $\left(0^{\circ} \mathrm{C}\right)$ & & & \\
\hline High $\left(20-30^{\circ} \mathrm{C}\right)$ & $30 \mathrm{kDa}$ & - & - \\
& $85 \mathrm{kDa}$ & + & + \\
& & & + \\
\hline
\end{tabular}

brane protein was probably phosphorylated at the histidyl residue. Phosphoamino acid analysis (Fujitaki \& Smith, 1978) of the alkali hydrolysate of the $30 \mathrm{kDa}$ protein upon paper chromatography confirmed that the protein was indeed phosphorylated at the histidyl residue (Fig. 5b). The kinetics of phosphorylation (Fig. 2) suggested that it was probably a histidine kinase since it is phosphorylated within $15 \mathrm{~s}$ of addition of $\left[\gamma^{32} \mathrm{P}\right]$ ATP or GTP to the kinase reaction mixture.

The phosphoamino acid in the membrane-bound $85 \mathrm{kDa}$ protein was both acid- and alkali-stable, indicating that it could be a phosphotyrosine. However, due to the small amount of radioactivity in the protein, direct phos- 
(a) $\begin{array}{lll}1 & 2 & 3\end{array}$

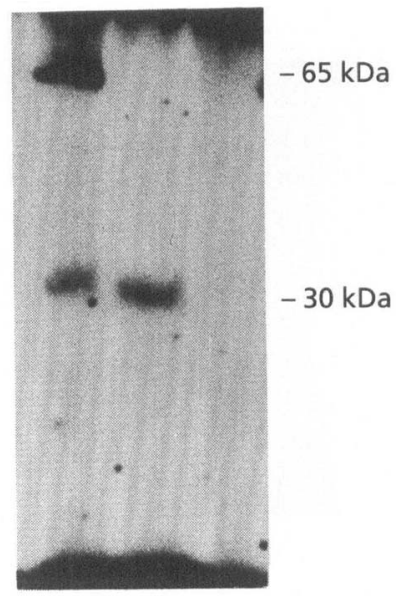

(b)

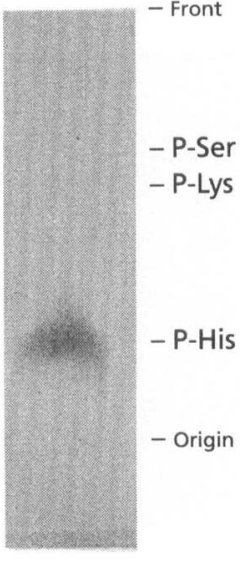

Fig. 5. Nature of phosphoamino acids in the phosphorylated proteins. (a) Acid- and alkali-stability of the phosphorylated proteins. The phosphorylated proteins were incubated in $0.1 \mathrm{M}$ Tris/ $/ \mathrm{HCl}, \mathrm{pH} 7.5$ (lane 1), $0.1 \mathrm{M} \mathrm{NaOH}$ (lane 2) or $0.1 \mathrm{M} \mathrm{HCl}$ (lane 3) for $20 \mathrm{~min}$ at $37^{\circ} \mathrm{C}$ following a phosphorylation reaction of the total membrane protein in the presence of [ $\left.\gamma_{-}{ }^{32} \mathrm{P}\right] \mathrm{ATP}$ at $0{ }^{\circ} \mathrm{C}$. The proteins were then subjected to $10 \%$ SDS-PAGE and autoradiography. (b) Phosphoamino acid analysis of the $30 \mathrm{kDa}$ membrane protein. The analysis was done by the method of Smith et al. (1978). The origin, solvent front and the position of P-Ser are marked. The positions of P-Lys and P-His have been marked from the $R_{F}$ values given by Smith et al. (1978).

phoamino acid analysis was not possible. The acid- and alkali-lability of the cold-induced phosphorylated $65 \mathrm{kDa}$ protein indicated that it was probably due to acyl phosphate. However, this protein retains its phosphate group during usual staining and destaining in presence of $7.5 \%$ acetic acid and therefore the exact nature of this phosphoamino acid could not be confirmed. It is also interesting to note that the $30 \mathrm{kDa}$ histidine phosphorylated protein did not lose its phosphate during standard staining-destaining of the gel in the presence of acetic acid, following SDS-PAGE. However, the protein lost its phosphate in $0.1 \mathrm{M} \mathrm{HCl}$ even after $15 \mathrm{~min}$ at $37^{\circ} \mathrm{C}$. The reason for this unusual stability of the protein in presence of acetic acid is not clear.

\section{Temperature sensing in psychrotrophic bacteria}

Sensing of temperature is an important aspect of adaptation of psychrotrophs to fluctuating environmental conditions. In this respect, the Antarctic psychrotrophic $P$. syringae has probably evolved a class of membrane proteins which can directly sense the external temperature by phosphorylation and dephosphorylation. The sensing of temperature in mesophiles such as $E$. coli by the proteins DnaK (McCarty \& Walker, 1991) and $\sigma^{32}$ (Straus et al., 1987), and in pathogenic bacteria such as Yersinia pestis by the activator protein LcrF (Hoe \& Goguen, 1993), may also be mediated through a similar modification of the membrane proteins which are yet to be identified. The possible involvement of the chemosensory proteins of the membrane in the sensing of temperature

\section{$\begin{array}{llllllllllllll}1 & 2 & 3 & 4 & 5 & 6 & 7 & 8 & 9 & 10 & 11 & 12 & 13 & 14\end{array}$}

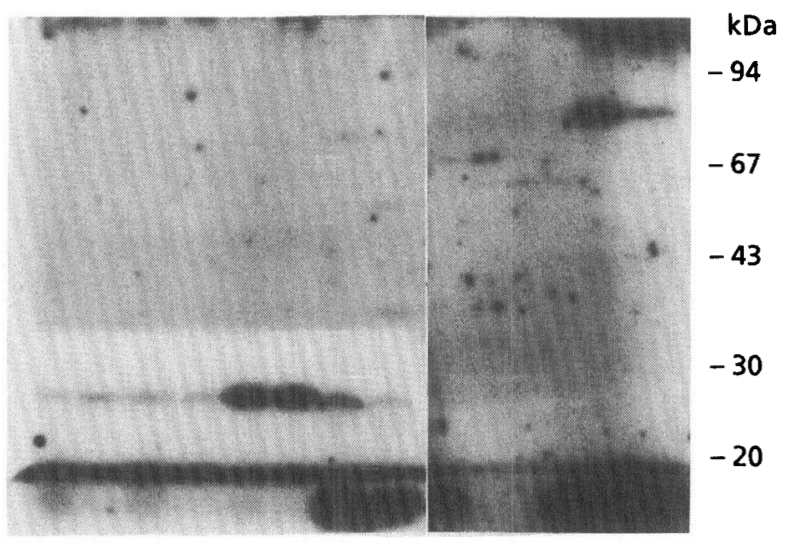

Fig. 6. In vitro phosphorylation of membrane proteins from various Antarctic psychrotrophs. Triton $X-100$ solubilized membrane proteins were phosphorylated in the presence of $[\gamma-$ 32P]ATP and analysed by SDS-PAGE and autoradiography. Phosphorylated proteins at, respectively, $0^{\circ} \mathrm{C}$ and $30^{\circ} \mathrm{C}$ of: $P$. fluorescens IW (lanes 1 and 2), P. fluorescens 9AW (lanes 3 and 4), P. fluorescens 39W (lanes 5 and 6), S. antarcticus 6BY (lanes 7 and 8), Micrococcus sp. 30Y (lanes 9 and 10), Planococcus sp. Lz3R (lanes 11 and 12) and $A$. globiformis 4B2W (lanes 13 and 14).

(Maeda \& Imae, 1979) in E. coli would require a more detailed study. Our proposed studies involving the purification of the membrane proteins and cloning of the possible 'sensor' and the 'regulator' genes by PCR amplification of conserved regions of these genes may shed some light on the thermosensory transduction in $P$. syringae. However, the question as to whether other psychrotrophic bacteria from Antarctica also sense environmental temperature by similar mechanisms remains unanswered. In this context, we studied the phosphorylation of membrane proteins from these bacteria in response to low $\left(0^{\circ} \mathrm{C}\right)$ and high $\left(30^{\circ} \mathrm{C}\right)$ temperatures in vitro in the presence of $\left[\gamma^{32} \mathrm{P}\right]$ ATP (Fig. 6). The results indicated that all representatives of the genera Pseudomonas and the newly identified species Sphingobacterium antarcticus (Shivaji et al., 1992) contained the $30 \mathrm{kDa}$ phosphorylated protein which is possibly a histidine kinase. The species belonging to the genera Micrococcus, Planococcus and Artbrobacter did not contain this protein but did contain different sets of proteins (Fig. 6) which were phosphorylated differently in response to low and high temperatures. Therefore, it is likely that various genera of bacteria may have evolved different sets of proteins to sense the environmental temperature. A note of caution must be added in respect of our postulate that the psychrotrophic bacteria sense environmental temperatures by phosphorylation-dephosphorylation of membrane and/or cytoplasmic proteins. Our study only indicates a correlation of phosphorylation-dephosphorylation events with the experimental temperatures. The results could as well be interpreted as involvement of the proteins in temperature-dependent metabolic activities of the cells, such as membrane transport and other similar processes. In summary, various psychrotrophic bacteria of Antarc- 
tica show temperature-dependent phosphorylation of membrane proteins. The molecular masses of the phosphorylated proteins among the various bacteria vary. One of the bacteria, a $P$. syringae isolate, which was studied in detail exhibited a specific set of membrane proteins $(30,65$ and $85 \mathrm{kDa}$ ) which were phosphorylated differently in response to low and high temperatures. These proteins might be responsible for primary sensing of environmental temperature, being transmitted through the cytoplasm for further propagation of the signal.

\section{REFERENCES}

Bourret, R. B., Borkovich, K. A. \& Simon, M. (1991). Signal transduction pathway involving protein phosphorylation in prokaryotes. Annu Rev Biochem 60, 401-441.

Chauhan, S. \& Shivaji, S. (1994). Growth and pigmentation in Sphingobacterium antarcticus, a psychrotrophic bacterium from Antarctica. Polar Biol 14, 31-36.

Craig, E. A. \& Gross, C. A. (1991). Is hsp 70 the cellular thermometer? Trends Biochem Sci 16, 135-140.

Fujitaki, J. M. \& Smith, R. A. (1984). Techniques in the detection and characterization of phosphoramidate-containing proteins. Methods Enzymol 107, 23-36.

Hoe, N. P., Minion, F. C. \& Goguen, J. D. (1992). Temperature sensing in Yersinia pestis: Regulation of yop $\mathrm{E}$ transcription by $l \mathrm{crF}$. $J$ Bacteriol 174, 4275-4286.

Hoe, N. P. \& Goguen, J. D. (1993). Temperature sensing in Yersinia pestis: translation of the $\mathrm{LcrF}$ activator protein is thermally regulated. J Bacteriol 175, 7901-7909.

Jagannadham, M. V., Jayathirtha Rao, V. \& Shivaji, S. (1991). The major carotenoid pigment of a psychrotrophic Micrococcus roseus: purification, structure and interaction of the pigment with synthetic membranes. J Bacteriol 173, 7911-7917.

Kyhse-Anderson, J. (1984). Electroblotting of multiple gels: a simple apparatus without buffer tank for rapid transfer of proteins from polyacrylamide to nitrocellulose. J Biochem Biophys Methods 10 , 203-209.

Laemmli, U. K. (1970). Cleavage of structural proteins during the assembly of the head of bacteriophage T4. Nature 227, 680-685.

Maeda, K. \& Imae, Y. (1979). Thermosensory transduction in Escherichia coli: inhibition of the thermoresponse by L-serine. Proc Natl Acad Sci US A 76, 91-95.

Martensen, T. M. (1984). Chemical properties, isolation, and analysis of O-phosphates in proteins. Methods in Enzymol 107, 3-23.

McCarty, J. S. \& Walker, G. C. (1991). DnaK as thermometer: threonine-199 is site of autophosphorylation and is critical for ATPase activity. Proc Natl Acad Sci US A 88, 9513-9517.

Mukai, K., Kawata, M. \& Tanaka, T. (1990). Isolation and phosphorylation of the Bacillus subtilis $\operatorname{deg} S$ and $\operatorname{deg} U$ gene products. $J$ Biol Chem 265, 20000-20006.

Ray, M. K. \& Shivaji, S. (1992). Antarctic microorganisms and cold adaptation. In Proceedings of D AE symposium on Molecular Biology of Microorganisms, NCL, Pune, India, pp. 278-283. Trombay, Bombay: Bhabha Atomic Research Centre.

Ray, M. K., Shivaji, S., Shyamala Rao, N. \& Bhargava, P. M. (1989).
Yeast strains from the Schirmacher Oasis, Antarctica. Polar Biol 9, 305-309.

Ray, M. K., Seshu Kumar, G. \& Shivaji, S. (1991). Plasmids from the soil bacteria of Schirmacher Oasis, Antarctica. Microbios 67, 151-157.

Ray, M. K., Uma Devi, K., Seshu Kumar, G. \& Shivaji, S. (1992). Extracellular protease from the Antarctic yeast Candida bumicola. Appl Environ Microbiol 58, 1918-1923.

Ray, M. K., Sitaramamma, T., Ghandhi, S. \& Shivaji, S. (1994a). Occurrence and expression of $\operatorname{csp} A$, a cold shock gene in Antarctic psychrotrophic bacteria. FEMS Microbiol Lett 116, 55-60.

Ray, M. K., Seshu Kumar, G. \& Shivaji, S. (1994b). Phosphorylation of lipopolysaccharides in the antarctic psychrotroph Pseudomonas syringae: a possible role in temperature adaptation. J Bacteriol 176, $4243-4249$.

Roy Chowdhury, S., Sakai, K. \& Chakrabarty, A. M. (1992). Alg R2 is an A'TP/GTP-dependent protein kinase involved in alginate synthesis by Pseudomonas aeruginosa. Proc Natl Acad Sci USA 89, 2659-2663.

Schnaitman, C. A. (1971). Solubilization of the cytoplasmic membrane of Escherichia coli by Triton X-100. J Bacteriol 108, 545-552.

Shivaji, S., Shyamala Rao, N., Saisree, L., Sheth, V., Reddy, G. S. N. \& Bhargava, P. M. (1988). Isolation and identification of Micrococcus roseus and Planococcus sp. from Schirmacher Oasis, Antarctica. J Biosci 13, 409- 414.

Shivaji, S., Shyamala Rao, N., Saisree, L., Sheth, V., Reddy, G. S. N. \& Bhargava, P. M. (1989a). Isolation and identification of Pseudomonas sp. from Schirmacher Oasis, Antarctica. Appl Environ Microbiol 55, 767-770.

Shivaji, S., Shyamala Rao, N., Saisree, L., Reddy, G. S. N., Seshu Kumar, G. \& Bhargava, P. M. (1989b). Isolates of Arthrobacter from the soils of Schirmacher Oasis, Antarctica. Polar Biol 10, 225-229.

Shivaji, S., Ray, M. K., Seshu Kumar, G., Reddy, G. S. N., Saisree, L. \& Wynn-Williams, D. D. (1991). Identification of Janthinobacterium lividum from the soils of the islands of Scotia Ridge and from Antarctica peninsula. Polar Biol 11, 267-272.

Shivaji, S., Ray, M. K., Saisree, L., Jagannadham, M. V., Seshu Kumar, G., Reddy, G. S. N. \& Bhargava, P. M. (1992). Spbingobacterium antarcticus sp. nov., a psychrotrophic halotolerant bacteria from the soils of Schirmacher Oasis, Antarctica. Int J Syst Bacteriol 42, 102-116.

Smith, R. A., Halpern, R. M., Bruegger, B. B., Dunlap, A. K. \& Fricke, O. (1978). Chromosomal protein phosphorylation on basic amino acids. Methods Cell Biol 19, 153-159.

Stock, J. B., Ninfa, A. J. \& Stock, A. M. (1989). Protein phosphorylation and regulation of adaptive response in bacteria. Microbiol Rev 53, 450-490.

Straus, D. B., Walter, W. A. \& Gross, C. A. (1987). The heat shock response of $E$. coli is regulated by changes in the concentration of $\sigma^{32}$. Nature 329, 348-351.

Straus, D. B., Walter, W. A. \& Gross, C. A. (1990). DnaK, Dna J and GrpI: heat shock proteins negatively regulate heat shock gene expression by controlling the synthesis and stability of $\sigma^{32}$. Genes Dev 4, 2202-2209.

Received 29 March 1994; revised 6 July 1994; accepted 26 July 1994. 